\title{
Assessing the Reliability of the Internal Audit Functions: The Issues
}

\author{
OKODO, Benedict Dozie \\ Department of Accounting, Faculty of Management Sciences University of Benin, Benin City, Edo State, Nigeria \\ Email:_dozieokodo@gmail.com \\ ALIU, Momodu Mohammed \\ Department of Accountancy, School of Business Studies, Auchi Polytechnic, Nigeria \\ Email: aliumuhammed389@gmail.com \\ YAHAYA, Adabenege Onipe \\ Department of Accounting and Management Faculty of Arts and Social Sciences Nigerian Defence Academy, Nigeria
}

Received: 15 August 2019; Revised: 20 September 2019; Accepted: 2 October 2019; Published: 24 October 2019

\begin{abstract}
This paper examines the issues in internal audit reliability. It specifically provides conceptual and practical insights into some of the consequential issues worth pondering about when assessing the reliability of the internal audit functions. Particularly, the paper identified and discussed four (4) of such issues namely: competency of internal auditors, level of management support/influence, independence and objectivity of internal auditors; and regulatory issues. The paper took a conceptual approach and draws its basis from the institutional and protection motivation theories. Based on literature and other documentary evidences, the paper took the position that the four identified factors would most likely influence the internal audit reliability. Among other policy implications, the paper, therefore, proposes a conceptual research framework to be empirically examined by future researchers.
\end{abstract}

Keywords: Internal auditing, Reliability, Auditor independence and Objectivity

\section{Introduction}

The sudden collapse of several large corporations like Enron and WorldCom shocked the corporate world in the early 2000 s and further increased the need for reliable internal control systems and corporate monitoring. Strengthening the corporate governance practices of organizations was among the salient measures proffered by several regulatory arrangements (such as Sarbanes-Oxley Act of 2002 in the United States) of different nations in a bid to curtail the incessant corporate failures among large corporations. Auditing is among the most crucial element of corporate governance structure within an organization.

Generally, the need for auditing (both internal and external) emanated due to the separation of the management from the ownership of companies - as statutorily practiced in virtually all listed companies around the world. While external auditing involves the statutorily examination of the financial information produced by the management in order to express an independent opinion on its trueness and fairness, internal auditing plays the role of ensuring that an organisation's risk management, governance and internal control processes are operating effectively (Chartered Institute of Internal Auditors, 2017). This makes the internal audit function (IAF) more central to the entire organizational success as its scope encompasses all the organizational units.

Consequently, the role of the internal auditors has been a subject of discussion among professional accountants and academics, particularly in the light of the revision of its definition by the Institute of Internal Auditors (IIA, 2001), which widened the scope of internal audit to evolve from its traditional compliance auditing to a stage where it is regarded as a value adding service to organizations (Arena \& Azzone, 2009; Suleiman \& Dandago, 2014). Alrjoub and Ahmad (2017) noted that internal audit existed in a rudimentary form prior to 1980 s, and was largely confined to checking compliances with organizational policies and procedures and verifying the existence of assets (Vani, 2010). However, by virtue of the new IIA's definition, internal audit as a concept now encompasses functions that go beyond assurance of internal financial operations. As Udeh and Nwadialor (2016, p.45) put it, "the main objective of the modern internal audit 
function is to assist management in making decisions by bringing a systematic, disciplined approach to evaluate and improve the effect of risk management, control, and governance process".

Specifically, the IIA in its latest definition defines internal auditing as an independent, objective assurance and consulting activity designed to add value and improve an organization's operations. It helps an organization to accomplish its objectives by bringing a systematic and disciplined approach to evaluate and improve the effectiveness of risk management, control, and governance processes. This enlarged role has increased the importance of internal auditing as part of the organization's management control system. At the same time it has also increased the demands being put on internal auditors. Their new role requires higher skills and knowledge than before. This means internal auditors' responsibilities are now broader and more demanding. Based on these responsibilities, the internal auditor has an important role in raising the reliability of the internal control system and improving the process of risk management.

In view of the concept of modern internal audit, scholars may wonder: i) how effective and reliable it has fared in both the private and public sector domain in developing countries, as well as ii) the issues to ponder about when assessing the reliability of internal audit functions. On the latter, as the major concern of this paper, several issues of concern have emanated in literature. The study of Coderre (2006) and Baharud-din, Shokiyah, and Ibrahim (2014) observed that i) questionable management support, ii) independence issues; and iii) scarcity of skilled resources were among the issues militating against the internal audit function in organizations. A recent 2015 study of Gunther Meggeneder from the "Global Institute of Internal Audit Common Body of Knowledge” (CBOK) which surveyed respondents from 166 countries, rated Africa at 36.5\% in terms of the proportion of internal audit reliability against stakeholders expectations. The study also identified issues such as competency, independence and objectivity of internal auditors as major issues of concern when assessing internal audit reliability. A more recent study by Oyewumi, Ayoib and Oluwatoyin (2017) specifically identified 'regulatory issues' as a major impediment to internal audit practice and reliability in most developing countries, such as Nigeria. This paper evaluates the four (4) aforementioned issues (issues of independence and objectivity of internal auditors; issue of management support/influence; issue of competency of internal auditors; and regulatory issues) with a view of charting the way forward for the enhancement of internal audit reliability in developing countries.

\subsection{Internal Auditing}

According to Unegbu and Obi (2012), internal audit is part of the internal control system put in place by management of an organization to ensure adherence to stipulated work procedure and as aid to management. Deepak (2010) sees internal audit as an independent and objective assurance and consulting function designed to help an organization to achieve its objectives. The Institute of Internal Auditors [IIA] (1999) defines internal auditing as an independent, objective assurance and consulting activity designed to add value and improve an organisation's operations. It assists an organization to achieve its objectives by bringing a systematic disciplined approach to evaluate and improve the effectiveness of risk management, control, and governance processes. Adeniji (2011) states that internal audit is part of the internal control system put in place by management of an organization to act as an aid to management which ensures that the financial operations are correctly carried out according to the law and also in accordance with the wishes of the board or council. Unegbu and Obi (2012) believe that internal audit measures, analyses and evaluates the efficiency and effectiveness of other controls established by management in order to ensure smooth administration, control cost minimization, capacity utilization and maximum benefit derivation. This implies that internal audit is an integral part of a complex system designed by the management of any organization to ensure orderly conduct of its business and prevent abuse of assets.

According to the IIA (2009) definition, internal auditing can as well be classified into three diverse areas; risk management, corporate governance and internal control. Internal auditors play a basic role not only in risk management but also providing consultants and assurance services to the executives. Previously, the IIA issued "The Role of Internal Auditing in Enterprise Wide Risk Management (ERM)" as a track to the internal auditors that they supposed to play their role in the enterprise risk management procedure. Lately, related to consulting services the IIA report portrays four essential activities for internal auditor to be accountable, which are; coordinating Enterprise-Wide Risk Management activities, facilitating the identification and evaluation of risks, maintaining and developing the Enterprise- Wide Risk Management framework, and for the management support developing of risk management strategy. Internal auditors are employed by individual companies to audit for management. The internal audit group in some firms (e.g. legal firms) can include over a hundred persons and typically reports directly to the CEO, other high executive officers or even 
the audit committee of board of directors. Internal auditors' responsibilities vary considerably, depending on the employer. Some internal audit staff consists of only one or two employees who may spend most of their time doing routine compliance auditing. Other internal audit staff may consist of numerous employees who have diverse responsibilities, including many outside accounting areas (Liu, 2013).

Enofe, Mgbame, Osa-Erhabor and Ehiorobo (2013) contend that the aim of internal auditing is to improve organizational efficiency and effectiveness through constructive criticism. This means that identification of areas of weakness and suggestions for improvement are the main thrust of internal auditing. Little wonder Sawyer (1995) state that internal auditor's job is not done until defects are corrected and remain corrected. Other researchers such as Deepak (2010) identify the objectives of internal auditing to include: Effectiveness and efficiency of operations (programmes and projects), reliability of financial and operational information, safeguarding of assets, compliance with rules and regulations and prevention and detection of fraud. Barker (1999) while corroborating the views of Owler and Brown (1999) extends the objective of internal audit to include review of the operations and records of the undertaking and in course of these checks, much of the detailed work of the organization in respect of financial and other statements are effectively audited. Vos (1997) also states the internal auditor's main objective is to evaluate effectiveness of financial and operating control, confirm compliance with company policies, procedure, protect assets, and verify the accuracy and consistency of organization's external and internal reports. While Stoner (1994) believes that the objective of internal audit is to evaluate several of the organization's reports for accuracy and usefulness and also recommending improvement of the control system, Owler and Brown (1999) argue that the objective of internal auditor is to protect management against errors of principle and neglect of duty.

In line with the provision of IIA (2011), the fundamental role of internal audit is to assist management to attain organization's goals. It also provides assurance that the management has implemented a satisfactory internal control system for risk prevention. In accumulating, internal audit provide internal consulting services to the whole organization in terms of facilitation, advices, training and counsels. Table 1 below presents a total of fifteen (15) internal audit functions, as identified from the literature.

Table 1.

List of Internal Audit Functions

\begin{tabular}{|c|c|}
\hline $\mathbf{S} / \mathbf{n}$ & Factor Items \\
\hline i. & Establishment of Accounting System \\
\hline ii. & Monitoring/Supervision of Accounting System \\
\hline iii. & Evaluation of Accounting System \\
\hline iv. & Design of Internal Control System \\
\hline $\mathrm{v}$. & Serving as Custodian of Internal Control System \\
\hline vi. & Soundness, Adequacy \& Application of ICS \\
\hline vii. & Ensuring Compliance. with Est. policies, Plans \& Procedures \\
\hline viii. & Examination of Financial Report before External Audit \\
\hline ix. & Economy, Efficiency \& Effectiveness of Operations \\
\hline $\mathrm{x}$. & Verifying the Existence of Assets \\
\hline xi. & Conducting Special Investigations \\
\hline xii. & Detailed Test of Transaction \& Balances \\
\hline xiii. & Human Resource Management \\
\hline xiv. & Security of documents (e.g. Audit trail) \\
\hline $\mathrm{xv}$. & Security of Information Technology (IT) Database \\
\hline
\end{tabular}

Source: Suleiman and Dandago (2014, p.228).

Taking cognizance of the above listed functions, Alberta (2005) as cited in Mu'azu and Siti (2013) states that internal auditors should possess the following characteristics in order to effectively carry out the above functions: Ability to align the structure of internal audit with the dynamics of the organizational operation; There should be strong relationship between management skills for maintaining appropriate visibility and audit committee needs and expectations; There should be strong service delivery capabilities (consistency in approach, standards, and delivery, including the abilities to maintain audit focus and alignment of resources to the plan; There should also be strong management skills which will ensure that internal audit teams have appropriate skills and motivation. Besides the above required characteristics, the level of training, education, experiences as well as professional qualifications of the internal auditors is equally as essential. 


\subsection{Conceptualizing Internal Audit Reliability}

Reliability can be seen as the extent to which the accounting information signifies what it purports to represent (Liu, 2013). How to ensure the reliability of internal auditing has been an area of common interest to many, though scarcely examined in literature. This paper sees internal audit reliability as the degree of assurance that the established objectives of the internal audit functions are achieved objectively and effectively. Traditionally, reliability is one of the anticipatable qualities of an audit assignment, be it external or internal audit. Prior literature (see Suleiman and Dandago, 2014) has shown that reliability of accounting information, in the context of contemporary financial audit, depends on the adequacy of a number of reliability factors, for example: have the financial statements been prepared based on Generally Accepted Accounting Principles (GAAP); having the financial statements approved by the directors; as well as been audited by independent auditor.

In respect of the external audit, the audited financial statement is expected to be reliable as anything short of that may undermine its decision usefulness. On the part of internal auditing, reliability can be linked from the effectiveness point of view of the entire internal audit process and function. Since the internal auditors are also employees of the organization - functioning in a staff capacity and reporting to the high-level officers in that organization, the reliability of their assignment could be scaled on three fronts. Firstly, on the part of the management: how well their input could be relied upon in assisting managements in strategic decision making, ensuring financial discipline and control, and minimizing/managing organizational risks. Secondly, on the part of the external auditor: their relationship with internal auditors should be one of mutual support and cooperation in order to strengthen overall audit quality and mechanisms of corporate governance as posited by Gramling and Myers (2003). How transparent and objective the internal auditors can be rated in this regards could translate to reliability of the internal audit function. Thirdly, effective stakeholder relationships: this is essential for internal audit's success. Fostering and strengthening stakeholder relationships helps to build confidence and reliability in internal audit's work (IIA, 2016).

\section{Issues in Internal Audit Reliability}

The study identified four salient issues from literature (see Coderre, 2006; Baharud-din, Shokiyah, and Ibrahim, 2014; Oyewumi, Ayoib and Oluwatoyin, 2017) that are considered vital in either enhancing or marring the internal audit reliability. They include: i) Issue of independence and objectivity of internal auditors; ii) Issues regarding management/stakeholders support and influence; iii) Issue of competency of internal auditors; and iv) regulatory issues.

\subsection{Issue of Independence and Objectivity of Internal Auditors}

Brinkley (2015) conceptualized independence and objectivity to be a reflection of an auditor that is selfsufficient, self-reliant, free from undue control, operationally autonomous, and thinking or acting for oneself. The IIA clearly recognizes internal auditing as an independent function in its definition and the internal auditors must be objective in performing their job. The standard describes independence as the freedom from conditions that threaten the ability of the internal audit activity to carry out internal audit responsibilities in an unbiased manner (Oyewumi et al, 2017). In that regards, the consensus in the literature (Alzeban \& Gwilliam, 2014; Gustavson \& Sundstrom, 2016; Tepalagul \& Lin, 2015) is that the principle of independence and objectivity is indispensable in both internal and external auditing. Both principles are considered as the cornerstones of auditing, and without them, the concept of auditing can merely be linked to that of a giraffe without a neck. Consequently, the regulators of accounting and auditing, through standards, lay much emphasis on the principle of independence and objectivity.

In actual practice, however, Okike (2004) reported that auditors in Nigeria have been rendered powerless, considering the environment they found themselves. Unegbu and Kida (2011) reports that internal auditors have become a toothless bulldog that can only bark but cannot bite, especially in the Nigerian public sector where they have been subjected to different categories of humiliation, ridicule, and maltreatment. Unegbu and Kida (2011, p.307) report that IAs are exposed to many hazards which impairs internal audit efficiency - such as the several "reported cases of assassinations, burglary, native medicine and acid attacks on the lives and properties of internal auditors".

Consequent upon this, Akharayi (2013) posits that the level of independence of IAs in Nigeria is very low, and in most cases, they are not objective in their recommendations and conclusions simply because of the fear of losing their job. This situation is not in line with the best practice and basic principle of independence and objectivity which is the cornerstone of the auditing profession. Howbeit, it has also been argued in the

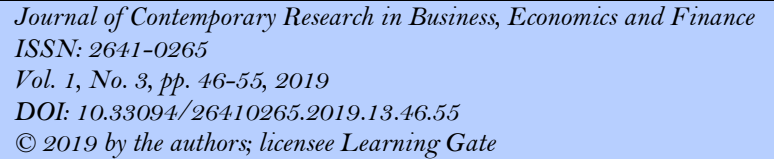


literature (see Mihret, James \& Mula, 2010; Tusek \& Pokrovac, 2012; Unegbu \& Kida, 2011) that, internal auditor, being an employee of an organization, cannot enjoy absolute independence. However, if the threat to the lives, properties, and possibility job loss of IAs continues, there is a high chance of them becoming a "toothless bulldog" that can only bark but cannot bite. This can threaten the reliability of their core mandate, and may implication affect the going concern potentials of the organization.

\subsection{Issues Regarding Management Support and Influence}

Some study (see Baharud-din et al, 2014) found that without management approval, support, and encouragement, the internal audit processes are likely to face failure. Before an internal audit function can be adjudged to be reliable, the auditor must have the support of the management. However, this appears not to be the case at all times. For instance, researchers like Akpomi and Amesi (2009) found that most Nigerian administrators feel auditors are always in their firm or establishment to expose them and so they prefer to have a cover up, by bribing them before the commencement or in the course of their duty. The authors also argue that most auditors connive with corrupt officials to cover their lapses. The possible explanations are not far-fetched, since internal auditors are also part of the workforce (employees) of the organization (unlike external auditors), there is every tendency that the management may either support or influence their duties. After all, "he who pays the piper dictates the tune". Also, Deribe \& Regasa (2014) suggest that if managers can control the quality of internal audit, they can easily engage in opportunistic behaviours without being noticed. The implication of the above is that an organization may still have an internal audit function, yet management excesses may not be curtailed especially where aspects of the function can be contained by management.

It was evidenced in a multiple-case study, as noted by Lenz (2013), that the pattern of interaction between Chief Audit Executives and Senior Management is a key determinant of Internal Audit effectiveness. This supports the earlier assertion that workability and reliability of the internal audit largely depends on the will power of the management to support such function. Therefore, where senior management, possibly pushed by the supervisory board or the owner himself, truly supports the internal audit function and wants it to look at the right matters, its effectiveness will be fundamentally different from cases where the management and/or board is passive, and does not push the internal audit function to become effective by unearthing matters they may not wish to be found. In the upper echelon of Management, interaction and relationship are strongly based on shared goals, shared knowledge and mutual respect. Since the duty of the internal auditors is to provide an unbiased and objective view, they ought to be free and exonerated from the operations they evaluate and report to the highest level in an organisation. If the internal auditor is given a level playing field to operate or is allowed to function without management interference in any form, there is every tendency that the audit exercise will be effective and reliable. More so, Baharud-din et al (2014) argued that the success of internal audit function will depend on the strength of management's support for the auditing process. Based on these lines of arguments, the paper proposes that a relationship would most likely between management support and internal audit reliability.

\subsection{Issue of Competency of Internal Auditors}

Baharud-din et al (2014) described competency as the ability of an internal auditor to perform a job or task properly base on the educational level, professional experience and the effort of the staffs for continuing professional development. To be effective, the internal audit activity must have qualified, skilled and experienced people who can work in accordance with the code of ethics and the international standards. In this regards, competence appears to be the watchword in the internal audit function. As per Prawitt, Smith and Wood (2008, p.9), "the more competent the internal auditors, the more likely they are to understand the factors leading to and the indicators of management bias in accounting accruals and how it can be moderated". The Statement of Accounting Standards (SAS) linked the internal auditors' competence to reliability of the audit assignments as SAS No. 65 indicates "that external auditors must evaluate an IAF"s competence, objectivity, and work performed before relying on the IAF's work".

The findings of most previous researchers equally towed the same direction. For example, researchers like Mpakaniye (2017) and Baharud-din et al (2014) found that audit staff competence is a significant determinant of an effective and reliable internal audit function. The study by Desai, Roberts and Srivastava (2006) also revealed that competence was the most important factor in a reliable internal audit function, followed by objectivity and work performance. Ege (2015) also find that IAF competence is negatively associated with the likelihood of management misconduct, meaning that a well-trained high quality IAF creates further benefits for the organization. The recent work of Eulerich and Ratzinger-Sakel (2017) equally note that internal 
auditors' competence and professionalism can be enhanced by engaging the internal audit staffs to periodic trainings. However, this appears not to be the case in all organizations. For example, Meggeneder (2015) argued that internal audit departments of most organization often do not have well-developed staff training after finding that only $40 \%$ of internal auditors in a survey of 166 countries reported fewer than 40 hours of training per year.

In Nigeria, as well as in most developed countries, auditors are seen as competent, but the failures of a handful of banks and some companies' have given rise to doubts in the minds of the business community (private and public sectors). Farouk and Hassan (2014) conducted a study of audit expectation gap in two southern states of Nigeria using 96 internal auditors in state ministries. Their study suggests that the widespread governance failures are a result of internal audit not been competent enough in performing its role. By virtue of the new definition of internal auditing by the IIA, which expanded the scope of internal auditing within an organization to encompass areas such as an organization's governance, risk management and management controls over: efficiency/effectiveness of operations (including safeguarding of assets), the reliability of financial and management reporting, internal auditors requires near-frequent skill developments for their functions to be reliable.

Baharud-din et al (2014) measured competency in terms of academic level, experience, the size of internal audit staffs, skill and the effort of the internal audit staffs and their employers in continuing professional development. In many instances, as noted by Akpomi and Amesi (2014), it is believed is that if the size (number) of internal auditors is not sufficient, then the whole audit process would be of no value. In that regards, Egbunike and Egbunike (2017) inadequate staffing can lead to mismanagement, error and abuse. They also note that the size of internal audit staff and their competency are the critical characteristics of internal audit quality that cannot be separated. However, they did not suggest the actual number of internal audit staffs an organization should engage in order to ensure greater competency and overall reliability of the audit outcome. This area poses great regulatory challenge since organizations are at liberty to engage as many or few internal auditors in their pay-roll at their discretion - depending on their size. Thus, the issue of competence of internal auditors is considered relevant in determining the internal audit reliability.

\subsection{Regulatory Issues}

Regulation can be described as a sustainable and focused control by a recognized entity or public agency over the engagement and activities that are valued by the society (Ambituuni, Amezaga, \& Emeseh, 2014). Researchers like Nzechukwu (2014) examined various provisions relating to internal auditing in Nigeria and identified various loop-holes in the areas of regulation, practice and administration. As Oyewumi, Ayoib and Oluwatoyin (2017, p.410) put it, "unlike external auditing, internal auditing is given less attention by the regulatory and statutory authorities in Nigeria", this calls for concern. Firstly, the guidelines and the standards issued by the global IIA are not mandatory for operational use in Nigeria especially in the public sector (Ebaid, 2011). This is because its chapter in Nigeria is yet to be statutory listed as a professional auditing body in Nigeria. However, the regulatory and statutory guide of Accounting and Auditing in Nigeria are conferred on the Institute of Chartered Accountants of Nigeria (ICAN), the Association of National Accountants of Nigeria (ANAN), and different enactment, rules and regulations emanating from the Government. The Nigerian Standards on Auditing (2013) issued by ICAN and the Profession Code of Conduct and Guide for Members by ICAN (2009), and ANAN (2014) mentioned the concept of independence in several pages. However, the standards, just like it is in the other global Accounting standards and the application of the codes are skewed towards external auditing. In the statutory angle, the Nigerian Companies and Allied Matters Act (1990 as amended) are meant to guide the operations of companies in relation to accounts and auditing. Similarly, this Act relates to external auditing. Generally, therefore, the attention of the regulatory and statutory framework is normally directed to external auditing (Alzeban \& Gwilliam, 2014). This position was corroborated by Nzechukwu (2014) who argued the CAMA emphasis has been more on external auditing its sections 357-369 devoted to the external auditor, while there is no statutory provision for internal auditing.

The Nigerian Public Accounts Committee Act promulgated in 1987 was established to examine the audited accounts of all offices and courts of the Federation and the Auditor-General's report thereon and other detailed matters as contained in section one. This Act further seeks to strengthen external auditing and does not address the issue of internal auditing. It is equally important to note that external audit function is post transactional, where as internal audit function is both pre and post transactional. See table 2 below for the distinctions between internal and external auditing. 
Table 2.

Differences between Internal and External Audit

\begin{tabular}{|l|l|l|}
\hline Key items & External Audit & Internal Audit \\
\hline Reports to & $\begin{array}{l}\text { Shareholders or members } \\
\text { who are outside the } \\
\text { organisations governance } \\
\text { structure. }\end{array}$ & $\begin{array}{l}\text { The board and senior management who are within the } \\
\text { organisations governance structure. }\end{array}$ \\
\hline Objectives & $\begin{array}{l}\text { Add credibility and } \\
\text { reliability to financial } \\
\text { reports from the } \\
\text { organisation to its } \\
\text { stakeholders by giving } \\
\text { opinion on the report. }\end{array}$ & $\begin{array}{l}\text { Evaluate and improve the effectiveness of governance, risk } \\
\text { management and control processes. This provides } \\
\text { members of the boards and senior management with } \\
\text { assurance that helps them fulfill their duties to the } \\
\text { organization and its stakeholders. }\end{array}$ \\
\hline Coverage & $\begin{array}{l}\text { Financial reports, financial } \\
\text { reporting risks. }\end{array}$ & $\begin{array}{l}\text { All categories of risk, their management, including } \\
\text { reporting on them. } \\
\text { Responsibility } \\
\text { for improvement to report problems. }\end{array}$ \\
\hline
\end{tabular}

Source: As adopted from Chartered Institute of Internal Auditors' [CIIA $]$ publication (2017, p.2)

Whereas external audit focuses on enterprise financial statements, internal audit is all encompassing of enterprise functions, including financial, operations, corporate governance, and compliance to laws, regulations, standards, company policies, procedures and ethics. Despite these regulatory issues, the approaches adopted by the regulatory authority (professional bodies), and statutory authority (government) appear to be theoretical and non-supervisory (Achua \& Alabar, 2014). This, therefore, leaves internal auditors at the mercy of the management (their employers) and the auditees. Considering that the job description of internal auditors may largely depends on organizational types and the terms of the internal auditor's engagement as noted by Liu (2013), the perceived absence of laid-down standards may encourage management's undue interference which may undermine the reliability of the entire assignment.

\section{Theoretical Underpinning}

The paper draws its theoretical backing on the combination of Institutional and Protection Motivation theories. On the former, the institutional theory is considered suitable for internal auditing (IA) research for three reasons. Firstly, the theory encompasses IA practices which are a part of organizational phenomena. Secondly, it helps to explain organizational phenomena without assuming a limited set of organizational goals-unlike neoclassical economic theories such as agency theory and transaction cost theory, which are both predicated on the assumption of shareholder wealth maximization which is not the only factor that an organization considers when trying to decide among alternative plans of actions (Mihret, James \& Mula 2010). Thirdly, it could support audit research in developing countries where the equity market is underdeveloped (Mihret, James \& Mula 2010). Prior research suggests that institutional theory has validity in IA research, both in developing countries (Al-Twaijry, Brierley \& Gwilliam, 2003) and developed countries (Arena, Arnaboldi \& Azzone 2006). Therefore, neoclassical economic theories may not sufficiently explain IA's development and operation in varied settings (Mihret, James \& Mula 2010).

The institutional theory proposes that the survival of an organization depends not only on achieving production efficiency but also on its conformity to societal norms of acceptable practice (DiMaggio \& Powell 1983). One of the prime characteristics of institutional theory according to Fogarty (1996) is its ability to contrast genuine achievements of organizations against what their structures may suggest to the external environment should be achieved. Institutional theory explains that organizations sometimes engage in decoupling, that is, actual organizational practice may differ from what the external facade of an organization suggests (Al-Twaijry, Brierley \& Gwilliam 2003). Subsequently, decoupling may occur when organizations display to the business world that they are operating in a perceived manner internally, when in the view of the external environment they are in fact falling short of those expectations (Meyer \& Rowan, 1977). In that regards, Al-Twaijry, Brierley and Gwilliam (2003) conclude that the actual operations of internal audit 
departments are often times decoupled from the expectations of how they operate and that prescribed by the International Standards for the Professional Practice of Internal Auditing (ISPPIA). They also believe that the tasks performed by internal audit departments are done without verification from outside agencies - which enables them to function according to their own business or organizational processes. Thus, the organizations may have internal audit departments, but these may not necessarily function in accordance with ISPPIA guidelines because of possible interferences from "insiders" which may end up undermining the reliability of the IA function. This leads us to the protection motivation theory.

The protection motivation theory, as propagated by Rogers (1975), proposes that fear is a catalyst of behavioural change (Solansky, 2014); the theory also outlines the protective mechanisms against the threat resulting from fear. The motivation to protect against oneself is based on three fundamental factors comprising i) the perceived severity of the threat, ii) the assumed probability of the occurrence of the event and, iii) the efficacy of the perceived preventive measure (Rogers, 1975). In linking the theory to this paper, the entire four (4) issues identified and discussed in this paper can be intertwined under this theory. In respect to 'fear' as the theory projects, the perceived consequences (on the part of the auditor) of not 'dancing to the tune of management' are fear of job loss, assassination, attacks, and operational and professional hazards (Oyewumi et al, 2017). As a consequence of this fear, the reliability of the IA function may be undermined since managerial influence may override that objectivity of the auditor (being an employee of the organization). This brings in the issue of regulation, as part of protective mechanisms proposed by the theory, to act as a benchmark and statutory backing in ensuring that internal auditors discharges their duties independently and objectively. Thus, the linkage of independence and objectivity, managerial support and regulation appears justifiable in the context of the protection motivation theory - which central themes revolves around threat, fear, and coping strategies (Rogers, 1975). With this understanding, this study employs a combination of Institutional and Protection Motivation theories.

Arising from the above theories, coupled with the expected integratedness between Independence and Objectivity of Internal Auditors, Management/Stakeholders support, of Internal Auditors, Regulatory issues (professional and statutory Regulation); and the internal audit reliability, the paper proposes a research framework (as shown below in Figure 1) which can be subjected to further empirical study.

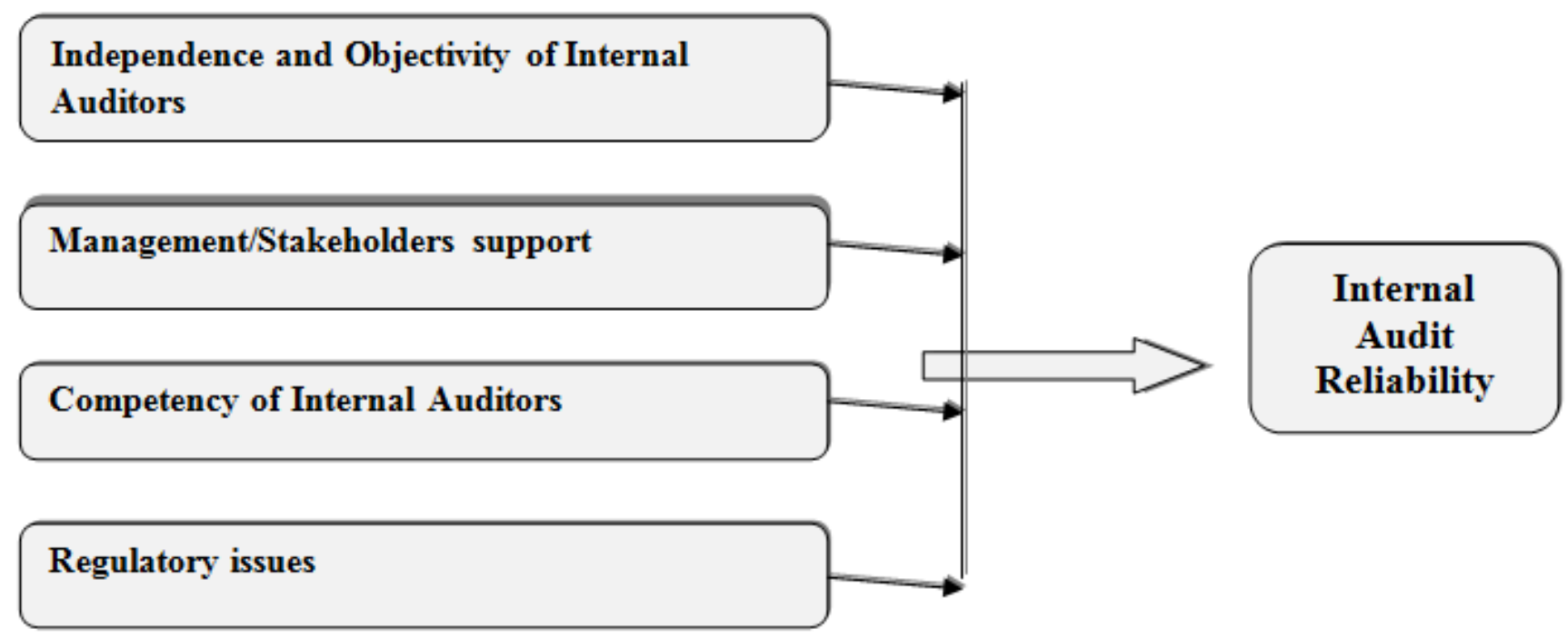

Source: Researcher Conceptualization (2017)

Figure-1. The Proposed Research Framework of the paper

\section{Conclusion}

This paper conceptually examined the issues in internal audit reliability. It identified and discussed four major issues from the perspective of independence and objectivity of internal auditors, competency of internal auditors, managerial support/influence, and issues relating to regulation. Based on literature and other documentary evidences, the paper takes the position that the four identified issues may likely influence internal audit reliability - either positively or negatively. In that regards, the paper proposes a research framework 
encompassing the four indentified factors as among the possible determinants of internal audit reliability in developing countries especially Nigeria.

The paper made some contributions and also harbors some policy implications. Firstly, it adds to the calls for the attention of the relevant bodies on the need for increased regulation (both governmental and professional) of internal audit activities in developing countries since the threat to auditor independence and objectivity appears more pressing on internal auditors as employees of organization, than their counterparts (external auditors) as external bodies. Secondly, it further reiterates the need for accounting professional bodies in developing countries to step-up their monitoring attention on internal auditing activities in order to enhance the reliability of their core mandates. By way of recommendation, the study calls for the empirical examination of the conceptual framework proposed in this paper in order to add to the existing research on internal audit reliability.

\section{References}

Adeniji, A.A. (2011). Auditing and Investigations. Wyse Associates Limited, Ikeja Nigeria.

Akpomi,M.E., \& Amesi, J. (2014). Behavioural constraints on practices of auditing in Nigeria (BCPAN). Educational Research and Review, 4(10), 465-469.

Alrjoub, A.M.S., \& Ahmad, M.A. (2017). Internal audit and its impact on risk management at the Islamic banks listed in Amman Stock Exchange.

Al-Twaijry, A.A.M., Brierley, J.A., \& Gwilliam, D.R. (2003). The development of internal audit in Saudi Arabia: an institutional theory perspective. Critical Perspectives on Accounting, 14(5), 507-531.

Arena, M. \& Azzone, G. (2009). Identifying organizational drivers of internal audit effectiveness. International Journal of Auditing, 13, $43-60$.

Arena, M., \& Azzone, G. (2007). Internal audit departments: adoption and characteristics in Italian companies. International Journal of Auditing, $11(2)$, 91-114.

Baharud-din, Z., Shokiyah, A., \& Ibrahim, M.S. (2014). Factors that contribute to the effectiveness of internal audit in public sector. Managerial Accounting Journal, $70(24)$, 126-132.

Barker, E. (1999). Organisation and management accounting. Hill Book Company Inc. New York.

Chartered Institute of Internal Auditors (2017). What is internal audit? Retrieved 18 December 2017 from https://na.theiia.org/about-us/about-ia/Pages/frequently-asked-questions.aspx

Coderre, D. (2006). Global technology audit guide: Continuous auditing implications for assurance, monitoring and risk assessment. Montvale, NJ: The Institute of Internal Auditors.

Deepak, J. (2010). PFM blog: internal audit in the public sector: Underdeveloped and underused. http://blogPFM.IMF.org/PFMblog/2010/08. Retrieved on December 15, 2017.

Desai, V., Roberts, R.W., \& Srivastava, R. (2006). An analytical model for external auditor evaluation of the internal audit function using belief functions. The Accounting Review. 68(7), 1-43.

DiMaggio, P., \& Powell, W. (1983). The iron cage revisited: institutional isomorphism and collective rationality in organizational fields. American Sociological Review, 48(2), 147-60.

Egbunike, P.A., \& Egbunike, F.C. (2017). An empirical examination of challenges faced by internal auditors in public sector audit in South-Eastern Nigeria. Asian Journal of Economics, Business and Accounting, 3(2), 1-13.

Ege, M. S. (2015). Does internal audit function quality deter management misconduct? The Accounting Review, 90(2), 495527.

Enofe, A.O., Mgbame, C.J., Osa-Erhabor, V.E. \& Ehioroba, A.J. (2013). The role of internal audit in effective management in public sector. Research Journal of Finance and Accounting, 4(6), $162-168$.

Eulerich, M., \& Ratzinger-Sakel, N. (2017). The effects of cultural dimension on the internal audit function: A worldwide comparison of internal audit characteristics. Contemporary Accounting Research, 29, 1-25.

Fogarty, T.J. (1996). The imagery and reality of peer review in the US: insights from institutional theory. Accounting Organizations and Society, 21, 243-68.

IIA (1999). The institute of internal auditors. Retrieved from www.theiia.org/index.cfm?doc_id=123

IIA (2011). Measuring internal audit effectiveness and efficiency. IPPF - Practice guide. The Institute of Internal Auditors.

ISPPIA. (2012). International standards for the professional practice of internal auditing (Standards). The Institute of Internal Auditors.

Meggeneder, G. (2015). Driving success in a changing world: 10 imperatives for internal audit. International Turkey Internal Audit Conference, 1-37.

Meyer, J., \& Rowan, B. (1977). Institutional organizations: Formal structure as myth and ceremony. The American Journal of Sociology, 83(2), 340-63.

Mihret, D.G, James, K., \& Mula, J.M. (2010). Antecedents and organisational performance implications of internal audit effectiveness: some propositions and research agenda. Pacific Accounting Review, 22(3), $224-52$. 
Mpakaniye, J.P. (2017). The effect of internal audit on the performance of decentralized entities in Rwanda. Retrieved December 10, 2017 from https://ssrn.com/abstract=3051075.

Nzechukwu, P. (2014). Proposed Nigeria internal audit regulatory, practice and admin agency and other related matters bill. Extracted on December, 22 2017 from https://www.linkedin.com/pulse/20141113085901-120827064proposed-nigeria-internal-audit-regulatory-practice-admin-agency-other-related-matters-bill

Owler, L. \& Brown, J.L. (1999). Cost and management accounting methods. London: Macdonald and Evans Press.

Oyewumi, H.K., Ayoib, B.C. \& Oluwatoyin, M.J. (2017). Internal auditors' independence and objectivity: Regulatory and statutory neglect. International Journal of Economics, Commerce and Management, 5(9), 410-423.

Rogers, R. W. (1975). A protection motivation theory of fear appeals and attitude change. Journal of Psychology, 91, 93114.

Solansky, S. T. (2014). To fear foolishness for the sake of wisdom: A message to leaders. Journal of Business Ethics, 122(1), 39-51.

Suleiman, D.M., \& Dandago, K.I. (2014). The extent of internal audit functions outsourcing by Nigerian deposit money banks. Procedia - Social and Behavioral Sciences, 164(14) $222-229$.

Udeh, S.N., \& Nwadialor, E.O. (2016). Evaluation of effectiveness of internal audit in the Nigerian public sector. European Journal of Business, Economics and Accountancy, 3(4), 44-58.

Unegbu, A.O. \& Obi, B.C. (2012). Auditing Hipuks, Enugu. Additional Press.

Vani, S. (2010). Internal audit in the public sector: Underdeveloped and underused. Retrieved from http://blogpfm.imf.org/pfmblog/2017/12.

Vos, P.M. (1997). Auditing practice. London: Macdonald \& Evans Press Ltd. 